\title{
The Metabolism of Urethane and Related Compounds
}

\author{
BY E. BOYLAND AND R. NERY \\ Chester Beatty Research Institute, Institute of Cancer Research: \\ Royal Cancer Hospital, London, S.W. 3
}

(Received 14 April 1964)

\begin{abstract}
1. Urethane is metabolized in the rat, rabbit and man by a process of $N$-hydroxylation. This occurs to a smaller extent when methyl, $n$-propyl and $n$-butyl carbamates are administered to the rat and rabbit. 2. Other metabolites which have been detected in urine of animals dosed with urethane and $N$-hydroxyurethane are ethylmercapturic acid, ethylmercapturic acid sulphoxide and $N$-acetyl- $S$ carbethoxycysteine. 3. Substances which appear to be $S$-ethylglutathione and $S$-ethylglutathione sulphoxide have been detected in the bile of rats dosed with urethane or $N$-hydroxyurethane. 4. Methyl, ethyl, $n$-propyl and $n$-butyl $N$ hydroxycarbamates are excreted unchanged in the urine of rats dosed with these compounds to extents depending on the dose administered. 5. Animals dosed with methyl, ethyl, $n$-propyl or $n$-butyl carbamate or the corresponding $N$-hydroxycarbamate excrete the corresponding carbamate and $N$-hydroxycarbamate in the urine. 6. Methyl, $n$-propyl and $n$-butyl carbamates and $N$-hydroxycarbamates are excreted more slowly than are urethane and $N$-hydroxyurethane. 7. The probable role of $N$-hydroxyurethane and the processes of alkylation and carbethoxylation, and of hydroxylamine, nitroxyl and hyponitrous acid in carcinogenesis and chemotherapy with urethane, have been discussed.
\end{abstract}

Urethane (ethyl carbamate) is carcinogenic to mice (Nettleship \& Henshaw, 1943), in which it induces hepatomas and lung adenomas (Law \& Precerutti, 1963) and lymphomas (Doell \& Carnes, 1962; Toth, Della Porta \& Shubik, 1961). It does not have an appreciable leukaemogenic action on adult mice (Tannenbaum, 1961; Berenblum \& Trainin, 1960; Kawamoto, Kirschbaum, Ibanez, Trentin \& Taylor, 1961), but induces leukaemia by a single injection into newborn mice (Fiore-Donati, Chieco-Bianchi, de Benedictis \& Maiorano, 1961), and augments leukaemogenesis by $\mathrm{X}$-rays (Berenblum \& Trainin, 1960, 1961), oestrogen or methylcholanthrene (Kawamoto, Ida, Kirschbaum \& Taylor, 1958). The effect as initiator of skin carcinogenesis in mice (Salaman \& Roe, 1953) is reduced if butyl carbamate is simultaneously administered (Garcia, 1963). Urethane is also carcinogenic to rats (Tannenbaum, Vesselinovitch, Maltoni \& Stryzak-Mitchell, 1962) and hamsters (Shubik et al. 1961). It retards growth of the Walker rat carcinoma 256 (Haddow \& Sexton, 1946), was used in the treatment of leukaemia in man (Paterson, ApThomas, Haddow \& Watkinson, 1946) and is used in the treatment of multiple myelomatosis (Loge \& Rundles, 1951). It produces chromosome damage in rat tissues similar to that produced by irradiation (Boyland \& Koller, 1954).
These effects are apparently specific for the ethyl carbamate, since the other homologues are inactive or less active (Berenblum et al. 1959). These authors have also reported that $N$-hydroxyurethane has the same carcinogenic activity as urethane when tested on the skin or lung of mice.

When administered to rats, urethane was evenly distributed in tissues within a few hours, metabolized and largely excreted in the expired air as carbon dioxide, and only about $4 \%$ of the dose appeared in the urine in $24 \mathrm{hr}$. (Boyland \& Rhoden, 1949; Skipper, Bryan, White \& Hutchison, 1948). Beikert (1951) reported an unidentified reducing substance in the urine of rabbits dosed with urethane. The nature of some of the metabolites of urethane and related substances in the urine of rat, rabbit and man and their possible modes of action are now reported.

\section{MATERIALS}

Spectra. Visible and ultraviolet-absorption spectra were recorded with a Perkin-Elmer model 137 ultraviolet spectrophotometer, infrared-absorption spectra on a Perkin-Elmer Infracord model 137 spectrophotometer and extinctions on a Unicam SP. 500 spectrophotometer.

Elementary analyses. These were by Weiler and Strauss, Oxford, England. 
Animals. Animals were kept in cages designed for the separate collection of urine and faeces. Urine was collected daily under toluene in receivers immersed in solid $\mathrm{CO}_{2}-$ acetone and stored at $-5^{\circ}$. Animals were injected intraperitoneally with methyl or ethyl carbamate as $20 \%(w / v)$ solutions in water, with $n$-propyl or $n$-butyl carbamate as $10 \%(w / v)$ solutions in arachis oil, or with methyl, ethyl, $n$-propyl or $n$-butyl $N$-hydroxycarbamate as $5 \%(w / v)$ solutions in water.

Chromatography. Whatman no. 1 chromatography paper (unless otherwise stated) was employed for descending development in the following solvent systems: $(a)$ butan-1. ol-propan-1-ol-aq. 2 N-NH $\mathrm{NH}_{3}$ (2:1:1, by vol.); (b) butan-1ol-acetic acid-water (12:3:5, by vol.). For thin-layer chromatography, glass plates were coated with films of silica gel G (E. Merck A.-G., Darmstadt, West Germany) of $0.25 \mathrm{~mm}$. thickness and the chromatograms were developed in (c) acetone-light petroleum (b.p. $\left.40-60^{\circ}\right)(3: 7, v / v)$, or (d) chloroform-acetone-light petroleum (b.p. $40-60^{\circ}$ ) (2:1:7, by vol.), or (e) ethanol-benzene-aq. $50 \%(\mathrm{v} / \mathrm{v})$ acetic acid ( $7: 1: 1$, by vol.). For the detection of compounds on chromatograms the following reagents were used: (i) ammoniacal aq. $2 \% \mathrm{AgNO}_{3}$; (ii) $0.1 \mathrm{M}-\mathrm{K}_{2} \mathrm{Cr}_{2} \mathrm{O}_{7}$-acetic acid $(1: 1, v / v)$ followed by $0 \cdot 1 \mathrm{M}-\mathrm{AgNO}_{3}$ (Knight \& Young, 1958); (iii) platinic iodide (Toennies \& Kolb, 1951); (iv) $p$ dimethylaminocinnamaldehyde $(2 \mathrm{~g}$. in $100 \mathrm{ml}$. of $6 \mathrm{~N}-\mathrm{HCl}$ and $100 \mathrm{ml}$. of ethanol) (Harley-Mason \& Archer, 1958); (v) $0.05 \%(w / v)$ ninhydrin in acetone, followed by heating the chromatograms at $85-90^{\circ}$ for 2-10 min.; (vi) NaIHCl-starch (Thompson, Arnold \& Morris, 1963b); (vii) 1\% (w/v) $\mathrm{FeCl}_{3}$ in aq. $50 \%$ ethanol, (viii) $1 \%(\mathrm{w} / \mathrm{v})$ sodium amminoprusside in water containing $0 \cdot 1 \%(w / v)$ of $\mathrm{MgCl}_{2}, 6 \mathrm{H}_{2} \mathrm{O}$. A Chromatolite lamp (Hanovia Ltd.) was used as a source of u.v. light.

Carbamates and $N$-hydroxycarbamates gave red spots with reagent (iv). $N$-Hydroxycarbamates gave purple colours with (vii) and reddish spots with (viii). $N$-Hydroxyurethane, its $N$ - and $O$-monosubstituted and $N O$-disubstituted derivatives gave dark spots with (i) after 5-10 min., 20-40 min. and 1-2 hr. respectively. $N$ - and $O$. Substituted $N$-hydroxycarbamates gave mauve colours with (viii). S-Substituted cysteines and glutathiones gave red to bluish-purple spots with (v) and yellow to brown spots with (ii), and sulphides and sulphoxides grey to brown spots on a red background with (iii). Sulphoxides also gave brown spots with (vi). The $R_{F}$ values of the compounds are given in Table 1.

Chemicals. Light petroleum was the fraction b.p. $60-80^{\circ}$, unless otherwise stated. Hydroxylamine hydrochloride (reagent grade) and ethyl carbamate were obtained from Hopkin and Williams Ltd., Chadwell Heath, Essex; methyl carbamate, sodium amminoprusside and methyl, ethyl and n-butyl chloroformates were from British Drug Houses Ltd., Poole, Dorset; $n$-propyl and $n$-butyl carbamates were from Eastman Kodak Ltd., Rochester, N.Y., U.S.A., and n-propyl chloroformate was from L. Light and Co. Ltd., Colnbrook, Bucks.

Alkyl N-hydroxycarbamates and derivatives. Methyl, ethyl, $n$-propyl and $n$-butyl $N$-hydroxycarbamates were prepared by the reactions of the corresponding alkyl chloroformates with hydroxylamine in the presence of $\mathrm{Na}_{2} \mathrm{CO}_{3}$ and ethyl $O$-acetyl-, ethyl $N O$-diacetyl- and ethyl $O$-carbethoxy- $N$ hydroxy-carbamates by the acetylation or carbethoxylation of $N$-hydroxyurethane, as described by Boyland \& Nery (1964b). In the preparation of $N$-hydroxyurethane, the crude oil obtained after evaporation of the ethereal extract distilled at $82-84^{\circ}(0.6 \mathrm{~mm}$.). In another preparation, the crude mixture was neutralized with $6 \mathrm{~N}-\mathrm{HCl}$ at $0^{\circ}$, evaporated to dryness in vacuo, the residue extracted with ethanol, the ethanol extract dried $\left(\mathrm{MgSO}_{4}\right)$ and the solvent evaporated off in vacuo. Attempted distillation of this residual oil at $0.6 \mathrm{~mm}$. caused an explosive decomposition when the

Table 1. $R_{F}$ values of reference compounds and their occurrence as metabolites of urethane and $\mathrm{N}$-hydroxyurethane in the urine of the rat and rabbit

For details of preparations etc., see text. +, Detected; - , not detected; $*$, probably produced by the spontaneous rearrangement of the $N$-isomer.

Occurrence as metabolite of

\begin{tabular}{|c|c|c|c|c|c|c|c|c|}
\hline \multirow[b]{2}{*}{ Compound } & \multicolumn{4}{|c|}{$R_{F}$} & \multicolumn{2}{|c|}{ Urethane } & \multicolumn{2}{|c|}{$\begin{array}{c}N \text {-Hydroxy- } \\
\text { urethane }\end{array}$} \\
\hline & $\ldots \quad(a)$ & (b) & (c) & $(d)$ & Rat & Rabbit & Rat & Rabbit \\
\hline Urethane & - & - & 0.35 & $0 \cdot 11$ & + & + & + & + \\
\hline$N$-Hydroxyurethane & - & 0.79 & $0 \cdot 23$ & 0.04 & + & + & + & + \\
\hline$O$-Acetyl- $N$-hydroxyurethane* & 一 & 一 & 0.45 & $0 \cdot 22$ & + & + & + & + \\
\hline$N$-Acetyl- $N$-hydroxyurethane & 一 & - & 0.48 & 0.24 & + & + & + & + \\
\hline$N O$-Diacetyl- $N$-hydroxyurethane & - & 一 & 0.59 & $0 \cdot 46$ & - & - & - & - \\
\hline$O$-Carbethoxy- $N$-hydroxyurethane & - & - & $0 \cdot 50$ & 0.26 & - & - & - & - \\
\hline$N O$-Dicarbethoxy- $N$-hydroxyurethane & - & - & $\mathbf{0 . 6 1}$ & $0 \cdot 48$ & - & 一 & - & - \\
\hline S-Ethylcysteine & $0 \cdot 27$ & 0.50 & - & - & - & - & + & - \\
\hline$S$-Ethylcysteine $S$-oxide & $0 \cdot 10$ & $0 \cdot 26$ & - & - & - & - & - & - \\
\hline$N$-Acetyl-S-ethylcysteine & $\mathbf{0 . 3 3}$ & 0.82 & - & 一 & + & + & + & + \\
\hline$N$-Acetyl-S-ethylcysteine $S$-oxide & $0 \cdot 29$ & 0.74 & - & 一 & - & - & + & + \\
\hline$S$-Carbethoxycysteine & $0 \cdot 25$ & 0.57 & - & 一 & - & - & - & - \\
\hline$N$-Carbethoxycysteine & $0 \cdot 30$ & 0.53 & - & - & - & - & - & - \\
\hline NS-Dicarbethoxycysteine & $0 \cdot 37$ & 0.83 & - & - & - & - & - & - \\
\hline$N$-Acetyl-S-carbethoxycysteine & $0 \cdot 35$ & 0.75 & 一 & - & + & + & + & + \\
\hline
\end{tabular}


bath temperature was $80-85^{\circ}$. The feasibility of distillation as a means of purification of this compound appears to depend upon the method of its preparation and the degree of its purity.

A solution of methyl $N$-hydroxycarbamate $(0.45 \mathrm{~g}$.) in benzene $(15 \mathrm{ml}$.) containing phenyl isocyanate $(0.65 \mathrm{~g}$.), after $16 \mathrm{hr}$. at $23^{\circ}$, was filtered, the filtrate evaporated in vacuo, and the residual semi-solid recrystallized from light petroleum to yield colourless needles of phenylcarbamoylmethyl N-hydroxycarbamate $\left(0.6\right.$ g.), m.p. $129^{\circ}$ (Found: C, 51.7; $\mathrm{H}, 5 \cdot 0 ; \mathrm{N}, 13 \cdot 7 . \mathrm{C}_{9} \mathrm{H}_{10} \mathrm{~N}_{2} \mathrm{O}_{4}$ requires $\mathrm{C}, 51 \cdot 4$; $\mathrm{H}, 4 \cdot 8 ; \mathrm{N}, 13 \cdot 3 \%$ ). Similarly prepared from the $N$-hydroxycarbamates and equimolar amounts of phenyl isocyanate in benzene were: (i) phenylcarbamoylethyl $\mathrm{N}$-hydroxycarbamate hemihydrate, m.p. $82^{\circ}$, as colourless plates from benzene-light petroleum (Found: C, 51.2; H, 5.7; N, 11.9. $\mathrm{C}_{10} \mathrm{H}_{12} \mathrm{~N}_{2} \mathrm{O}_{4}, \frac{1}{2} \mathrm{H}_{2} \mathrm{O}$ requires $\mathrm{C}, 51 \cdot 5 ; \mathrm{H}, 5 \cdot 6 ; \mathrm{N}, 12.0 \%$ ), which gave phenylcarbamoylethyl $\mathrm{N}$-hydroxycarbamate after drying over $\mathrm{P}_{2} \mathrm{O}_{5}$ at $60^{\circ}$ (15 mm.) for $1 \mathrm{hr}$., m.p. $83^{\circ}$, as colourless plates (Found: C, 54.0; H, 5.4; N, 12.2. $\mathrm{C}_{10} \mathrm{H}_{12} \mathrm{~N}_{2} \mathrm{O}_{4}$ requires $\mathrm{C}, 53 \cdot 6 ; \mathrm{H}, 5 \cdot 4 ; \mathrm{N}, 12.5 \%$ ); (ii) phenylcarbamoyl-n-propyl N-hydroxycarbamate, m.p. $110^{\circ}$, as colourless plates from benzene-light petroleum (Found: C, 55.3; $\mathrm{H}, 6 \cdot 2 ; \mathrm{N}, 12 \cdot 1 . \mathrm{C}_{11} \mathrm{H}_{14} \mathrm{~N}_{2} \mathrm{O}_{4}$ requires $\mathrm{C}, 55 \cdot 45$; $\mathrm{H}, 5.9 ; \mathrm{N}, 11 \cdot 8 \%$ ); (iii) phenylcarbamoyl-n-butyl N-hydroxycarbamate, m.p. $118^{\circ}$, as colourless plates from light petroleum (Found: $\mathrm{C}, 57 \cdot 4 ; \mathrm{H}, 6 \cdot 2 ; \mathrm{N}, 11 \cdot 1 . \mathrm{C}_{12} \mathrm{H}_{16} \mathrm{~N}_{2} \mathrm{O}_{4}$ requires $\mathrm{C}, 57 \cdot 1 ; \mathrm{H}, 6 \cdot 4 ; \mathrm{N}, 11 \cdot 1 \%$ ). Yields of recrystallized materials were $80-85 \%$.

Infrared spectra. $N$-Hydroxyurethane showed bands at 3300 ( $\mathrm{N}-\mathrm{H}$ stretching), 2995, 1745 ( $\mathrm{C}=\mathrm{O}$ stretching), $1490,1450,1382,1340,1263$ (C-O stretching), 1171, 1120 (C-O stretching), 1060, 1030 and $775 \mathrm{~cm}^{-1}$. The band at $3300 \mathrm{~cm} .^{-1}$ was also present in the monoacetyl, monocarbethoxy and phenylcarbamoyl derivatives, indicating that these compounds possessed the general structure $\mathrm{R} \cdot \mathrm{O} \cdot \mathrm{CO} \cdot \mathrm{NH} \cdot \mathrm{O} \cdot \mathrm{R}^{1}$, where $\mathbf{R}^{1}$ was the substituent group; it was absent from $N O$-diacetyl- $N$-hydroxyurethane. No attempt was made to determine the contribution of the tautomeric hydroximic acid form, $R \cdot O \cdot C(O H): N \cdot O \cdot R^{1}$, to the structure of the $N$-hydroxycarbamates or their mono- $O$-substituted derivatives.

Solutions of the alkyl $N$-hydroxycarbamates in $\mathrm{N}-\mathrm{NaOH}$ or $5 \%$ sodium ethoxide in ethanol formed the corresponding alkyl carbonates and, on standing, $\mathrm{Na}_{2} \mathrm{CO}_{3}$. A solution of $N$-hydroxyurethane $(0.2 \mathrm{~g}$.) and $N$-acetylcysteine $(0.3 \mathrm{~g}$. $)$ in $5 \%(\mathrm{w} / \mathrm{v}) \mathrm{NaHCO}_{3}\left(5 \mathrm{ml}\right.$.), after $40 \mathrm{hr}$. at $23^{\circ}$, contained small amounts of $N$-acetyl-S-carbethoxy-and $N$-acetyl- $S$ ethyl-cysteine detected by paper chromatography in solvents $(a)$ and $(b)$. Cysteine hydrochloride $(0 \cdot 3 \mathrm{~g}$.), under similar conditions, formed $S$-carbethoxy- and $S$-ethylcysteine. When urethane was incubated with acetylcysteine or cysteine no $S$-carbethoxy and $S$-ethyl derivatives appeared to be formed.

$S$-Ethylcysteine and $S$-ethylcysteine sulphoxide were prepared as described by Roberts \& Warwick (1958). Ethyl mercapturic acid and its dicyclohexylammonium salt were prepared as described by Thompson, Barnsley \& Young (1963a).

$\mathrm{N}$-Acetyl-S-carbethoxycysteine. Ethyl chloroformate (2.5 g.) was added dropwise to a stirred solution of $N$-acetylcysteine (3 g.) and $\mathrm{NaHCO}_{3}(6 \mathrm{~g}$.$) in water (50 ml.). Stirring$ was continued until a negative nitroprusside test (about $45 \mathrm{~min}$.) for free thiol was obtained and then for a further hour. The mixture was acidified to $\mathrm{pH} 4.0$ with acetic acid, extracted with chloroform $(4 \times 30 \mathrm{ml}$.), the combined chloroform extracts were washed with water $(20 \mathrm{ml}$.), dried $\left(\mathrm{Na}_{2} \mathrm{SO}_{4}\right)$, and evaporated in vacuo to yield a colourless residual oil, which did not crystallize, but appeared to be chromatographically homogeneous, gave positive reactions with reagents (ii) and (iii) and negative reactions with ninhydrin or nitroprusside. After heating with $4 \mathrm{~N}-\mathrm{HCl}$ at $100^{\circ}$ for $1 \mathrm{hr}$, it formed $S$-carbethoxycysteine, which gave a positive ninhydrin reaction (with reagent $v$ ) and a negative nitroprusside reaction. With diazomethane in methanolether, it gave an oil, b.p. $154-156^{\circ}(0.5 \mathrm{~mm}$.), which solidified and gave the methyl ester as fine colourless needles from light petroleum, m.p. $50-51^{\circ}$ (Found: C, 43.5; H, 6.3; N, 5.6; $\mathrm{S}, 12.6$; mol.wt., 236. $\mathrm{C}_{9} \mathrm{H}_{15} \mathrm{NO}_{5} \mathrm{~S}$ requires $\mathrm{C}, 43 \cdot 4 ; \mathrm{H}, 6 \cdot 1$; $\mathrm{N}, 5 \cdot 6 ; \mathrm{S}, 12.9 \%$; mol.wt., 249). On heating with $4 \mathrm{~N}-\mathrm{HCl}$ at $100^{\circ}$ for $1 \mathrm{hr}$., this compound gave $S$-carbethoxycysteine. After $24 \mathrm{hr}$. in $2 \mathrm{~N}-\mathrm{NaOH}$ at $23^{\circ}$, it gave ethylmercapturic acid, $N$-acetylcysteine and $N N^{\prime}$-diacetylcystine.

The following compounds were obtained as chromatographically homogeneous specimens, but were not further characterized: (i) $\mathrm{N}$-Acetyl-N-hydroxyurethane, a minor component of the products of acetylation of $N$-hydroxyurethane with acetic anhydride or of the carbethoxylation (with ethyl chloroformate) of acetohydroxamic acid, was eluted with ether from silica gel scraped off the appropriate $R_{F}$ region after development of thin-layer chromatograms in solvent system (c). It rearranged to the $O$-isomer on standing at room temperature, and was slowly hydrolysed in water to $N$-hydroxyurethane. The $O$-isomer, by contrast, did not rearrange, was slowly hydrolysed by warm water, and readily so by cold aq. $2 \mathrm{~N}-\mathrm{NH}_{3}$ soln., $\mathrm{N}-\mathrm{NaOH}$ or $\mathrm{N}-\mathrm{HCl}$, to yield $N$-hydroxyurethane. (ii) S-Carbethoxycysteine. Ethyl chloroformate (1 g.) was added dropwise over $20 \mathrm{~min}$. to a rapidly stirred solution of cysteine hydrochloride (1.5 g.) in water $\left(60 \mathrm{ml}\right.$.) containing $\mathrm{NaHCO}_{3}(3 \mathrm{~g}$.). After $4 \mathrm{hr}$., the resulting solution was adjusted to $\mathrm{pH} 3.0$ with $4 \mathrm{~N}-\mathrm{HCl}$, extracted with chloroform $(3 \times 25 \mathrm{ml}$.$) , the combined$ chloroform extracts were washed with water $(2 \times 15 \mathrm{ml}$.), dried $\left(\mathrm{Na}_{2} \mathrm{SO}_{4}\right)$, and evaporated in vacuo to yield the title compound as a colourless gum. Elution with chloroform of the appropriate strips cut from chromatograms (3 MM chromatography paper) developed in solvent system (b), followed by evaporation of the solvent in vacuo, afforded chromatographically pure $S$-carbethoxycysteine. This compound gave a positive ninhydrin but a negative nitroprusside reaction. (iii) NS-Dicarbethoxycysteine was similarly obtained as a colourless gum from the reaction of ethyl chloroformate $(2 \cdot 2 \mathrm{~g}$.) with cysteine hydrochloride ( $1.5 \mathrm{~g}$.) in water $\left(50 \mathrm{ml}\right.$.) containing $\mathrm{NaHCO}_{3}$ (3.6 g.). (iv) $\mathrm{NN}^{\prime}$-Dicarbethoxycystine was similarly obtained from the reaction of ethyl chloroformate $(1 \cdot 2 \mathrm{~g}$.) with cystine (1.2 g.) in aq. $\mathrm{NaHCO}_{3}$. (v) N-Carbethoxycysteine was obtained as a colourless gum by decomposition of the lead salt with $\mathrm{H}_{2} \mathrm{~S}$ after reduction of (iv) with zinc dust- $\mathrm{HCl}$ in a manner similar to that described for the preparation of $N$-acetylcysteine (Pirie \& Hele, 1933). It gave a positive nitroprusside and a negative ninhydrin reaction.

On heating under reflux with $5 \%(w / v) \mathrm{KOH}$ in $90 \%$ ethanol, compounds (i)-(v), and all the other carbalkoxy derivatives (e.g. the $N$-hydroxycarbamates), deposited $\mathrm{K}_{2} \mathrm{CO}_{3}$. On heating at $100^{\circ}$ with $6 \mathrm{~N}-\mathrm{HCl}$, ethylmercapturic acid sulphoxide gave $S$-ethylcysteine and $S$-ethylcysteine sulphoxide; with thioglycollic acid, it gave ethylmercapturic 
acid (cf. Thompson \& Young, 1960). On heating with $6 \mathrm{~N}-\mathrm{HCl}$ at $100^{\circ}$ for $2 \mathrm{hr}$., $N$-carbethoxycysteine gave cysteine, and $N$-acetyl-S-carbethoxy- and NS-dicarbethoxy-cysteine gave $S$-carbethoxycysteine and other unidentified products. In alkaline media, $S$-carbethoxycysteine rearranged to $N$-carbethoxycysteine (cf. Schoental \& Rive, 1963).

Examination of urine. Urine of animals and patients dosed with urethane or $N$-hydroxyurethane was treated as follows; treatment was controlled by comparison with normal urine collected before dosing. Urine was adjusted to $\mathrm{pH} 7.0$ with acetic acid and extracted continuously with ether for $16 \mathrm{hr}$. The ether extract was dried $\left(\mathrm{Na}_{2} \mathrm{SO}_{4}\right)$, evaporated in vacuo at $20^{\circ}$, and the residual gum examined for urethane, $N$-hydroxyurethane and other neutral components. Part of the aq. layer (aq. fraction 1, Scheme 1) was set aside for enzymic hydrolysis experiments and the rest adjusted to $\mathrm{pH} 2.0$ with $10 \mathrm{~N}-\mathrm{HCl}$ and extracted with chloroform until no more products were extracted. The combined chloroform extract, after drying $\left(\mathrm{Na}_{2} \mathrm{SO}_{4}\right)$, was evaporated in vacuo and the residual gum examined for the presence of ethylmercapturic acid, ethylmercapturic acid sulphoxide, $N$-acetyl-S-carbethoxycysteine and other chloroform-soluble acidic components. The aq. layer (aq. fraction 2, Scheme 1) was stirred with charcoal (5-10 g.), the charcoal filtered off, washed with water until washings were neutral, stirred with methanol containing $5 \%(\mathrm{v} / \mathrm{v})$ of aq. $\mathrm{NH}_{3}$ (sp.gr. $0 \cdot 88$ ), filtered off, the filtrate evaporated in vacuo, and the residue examined for the presence of $S$-ethylcysteine and other metabolites. The $\mathrm{pH}$ of the combined aq. filtrate and washings (aq. fraction 3, Scheme 1) was adjusted to 4.0 with $4 \mathrm{~N}-\mathrm{NaOH}$ and the glucuronosidates were precipitated as lead salts and regenerated with $\mathrm{H}_{2} \mathrm{~S}$ (cf. Smith \& Williams, 1949).

\section{METHODS}

Determination of carbamates. The method, which is a modification of that described by Devaux, Mesnard \& Cren
(1963), is based on the fact that ethanolic KOH converts carbamates into cyanate, which gives a blue cobalt complex. The method finally employed was as follows. The urine sample containing carbamate was neutralized with $\mathrm{N}-\mathrm{HCl}$ or N-KOH, extracted with 2 equal volumes of ether, the combined ethereal extracts were dried $\left(\mathrm{Na}_{2} \mathrm{SO}_{4}\right)$ at $0^{\circ}$, filtered and the residue was washed through with $20 \mathrm{ml}$. of ice-cold ether, the ether fraction evaporated to dryness at $20^{\circ}(15 \mathrm{~mm}$.) in a rotary film evaporator and the residue dissolved in ethanol $(6 \mathrm{ml}$.). The rest of the procedure also applies to the direct estimation of carbamates dissolved in ethanol, as follows: portions ( $2 \mathrm{ml}$.) of the ethanolic solution were treated with $5 \cdot 6 \%(\mathrm{w} / \mathrm{v}) \mathrm{KOH}$ in aq. $90 \%$ ethanol $\left(0.5 \mathrm{ml}\right.$.), mixed, heated at $70^{\circ}$ for $1 \mathrm{hr}$. in stoppered tubes, cooled in ice-water, and treated with acetic acid (0.075 ml.) and ethanolic $1 \%(\mathrm{w} / \mathrm{v}) \mathrm{CoCl}_{2}(0.1 \mathrm{ml}$.); the total volume was made up to $4 \mathrm{ml}$. with ethanol, and the extinction determined at $610 \mathrm{~m} \mu$ against a blank made up similarly but containing no carbamate.

When methyl, ethyl, $n$-propyl and $n$-butyl carbamates were dissolved in ethanol and determined in this way, they gave solutions having molar extinction coefficients (calculated on the concentrations of the final solutions) $\mathbf{4 5 . 0}$, 49.8, 51.5 and 49.7. Compared with $\epsilon 88.0$ for potassium cyanate, these figures indicate the extent to which the carbamates were converted into cyanate under the conditions employed. Since no higher values were obtained on longer heating, it is probable that about half of the carbamate present was decomposed by some other route, e.g. to yield $\mathrm{NH}_{3}, \mathrm{CO}_{2}$ and an alcohol. When added to normal rat or human urine the four carbamates were recovered to the extent of $20,43,57$ and $65 \%$ respectively; these figures reflect the partition coefficients of the carbamates in urineether. Urea and $N$-hydroxyurea in ethanol, estimated as above, gave solutions having $\epsilon \mathbf{0 . 8 4}$ and $48 \cdot 6$ respectively. Methyl, ethyl, $n$-propyl, $n$-butyl and ethyl $O$-acetyl- $N$ hydroxycarbamates did not yield cyanate with alkali and so did not interfere.

Determination of $\mathrm{N}$-hydroxycarbamates. N-Hydroxycarbamates, like the $N$-arylhydroxylamines (Boyland \&

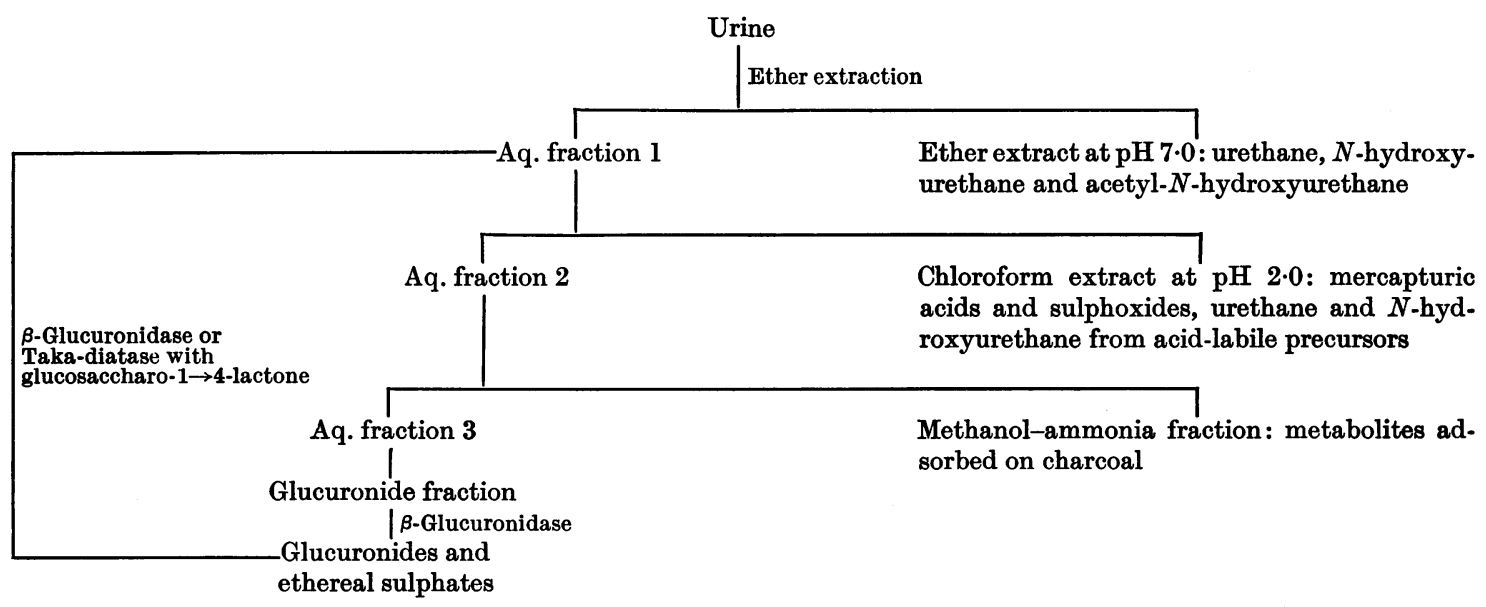

Scheme 1. Fractionation of metabolites from the urine. Experimental details are given in the text. 
Nery, 1964a), give coloured pentacyanoferroate complexes (I) in the presence of $\mathrm{Mg}^{2+}$ ions:

$$
\begin{aligned}
\mathrm{R} \cdot \mathrm{O} \cdot \mathrm{CO} \cdot \mathrm{NH}(\mathrm{OH})+\left[\mathrm{Fe}(\mathrm{CN})_{5} \cdot \mathrm{NH}_{3}\right]^{3-} \stackrel{\mathrm{Mg}^{2+}}{\longrightarrow} \\
{\left[\mathrm{Fe}(\mathrm{CN})_{5} \cdot \mathrm{R} \cdot \mathrm{O} \cdot \mathrm{CO} \cdot \mathrm{NH}(\mathrm{OH})\right]^{3-}+\mathrm{NH}_{3} }
\end{aligned}
$$

The methods used for their determination in water and urine solutions were those described by Boyland \& Nery $(1964 b)$. Urine samples were first acidified to $\mathrm{pH} 4$ with acetic acid, shaken with charcoal, filtered and the filtrate was adjusted to $\mathrm{pH} \mathbf{7 \cdot 5}$ with $\mathrm{N}-\mathrm{NaOH}$ before the reagents were added. When doubtful results were obtained, i.e. when the concentration of the $N$-hydroxycarbamate in urine was too low, the neutralized filtrate was evaporated to dryness in vacuo at $35-40^{\circ}$, the residue dissolved in ethanol, filtered, the filtrate evaporated in vacuo, the residue dissolved in a small volume of water and the determination carried out on $3.5 \mathrm{ml}$. portions. The $N$-hydroxycarbamates added to normal rat or human urine were quantitatively recovered after such treatment. For the determination in ether extracts of large volumes of urine, the ether was removed by evaporation in a rotary film evaporator at $15^{\circ}(15 \mathrm{~mm}$.), the residue dissolved in a suitable volume of water and the determination carried out on $3.5 \mathrm{ml}$. portions.

The method was used to determine the stability of solutions of $N$-hydroxyurethane at $22^{\circ}$. It was stable at pH 6.5-7.5, less stable in alkali than in acid, and more stable in water than in urine. In urine at $\mathrm{pH} 7 \cdot 0, N$-hydroxyurethane decomposed to the extent of 4 and $34 \%$ after 16 and $56 \mathrm{hr}$. at $22^{\circ}$ respectively; in water, the corresponding figures were 0.4 and $7 \%$.

Determination of ethylmercapturic acid. The method used was essentially that described by Maw (1956) and modified by Thompson et al. (1963a) and depends on the colour given by the ethylmercapturic acid-sodium nitroprusside complex in acid solution. Under the conditions employed, ethylmercapturic acid and $S$-ethylcysteine gave red solutions $\left(\lambda_{\max } 518 \mathrm{~m} \mu\right)$ having molar extinction coefficients (calculated on the concentrations of the final solutions) 57.8 and 30.4 respectively. The corresponding sulphoxides or $N$-acetyl-S-carbethoxycysteine did not interfere. Ethylmercapturic acid could not be determined directly in urine solutions, but only after extraction. The urine containing ethylmercapturic acid was acidified to $\mathrm{pH} 2.0$ with $6 \mathrm{~N}-\mathrm{HCl}$ and extracted twice with equal volumes of chloroform. The combined chloroform extracts were evaporated to dryness in vacuo, the residue was dissolved in water $(6 \mathrm{ml}$.) and portions $(2.5 \mathrm{ml}$.) were treated with $0.25 \mathrm{ml}$. of $1.34 \%(\mathrm{w} / \mathrm{v})$ sodium nitroprusside and $0.5 \mathrm{ml}$. of $5 \mathrm{~N}-\mathrm{NaOH}$. After 20 min. the solutions were cooled in ice-water, $1 \mathrm{ml}$. of $88 \%$ phosphoric acid was added, the contents were mixed and the extinctions determined at $518 \mathrm{~m} \mu$ in a $1 \mathrm{~cm}$. cell against a blank made up similarly from an equal volume of normal urine. The recovery of ethylmercapturic acid added to urine, under these conditions, was $27-30 \%$.

Determination of N-acetyl-S-carbethoxycysteine. The estimation of this compound was based on the observation (on chromatographic evidence) that it was the only observed metabolite, in addition to ethyl mercapturic acid, which was capable of yielding a steam-distillable thiol from acid solution after alkaline hydrolysis. Like the $S$-ethyl and $S$-pheny] esters (Otto \& Rossing, 1886) of ethyl thio- carbonate, which gave diethyl and ethyl phenyl sulphides respectively on alkaline hydrolysis, $N$-acetyl-S-carbethoxycysteine yielded small amounts of ethylmercapturic acid and, probably, some ethyl thiocarbonate; the latter, on acidification, is known to give carbon oxysulphide, which is hydrolysed to $\mathrm{H}_{2} \mathrm{~S}$ and $\mathrm{CO}_{2}$. When a solution of $\mathrm{N}$-acetyl$S$-carbethoxycysteine in urine was subjected to alkaline hydrolysis, acidified and steam-distilled, 15-20\% of the theoretical amount of thiol compounds appeared in the steam-distillate. This may indicate that the major products of alkaline degradation are ethanol, $\mathrm{CO}_{2}$ and $\mathrm{N}$-acetylcysteine. The recovery of ethylmercapturic acid was $30-33 \%$.

The method used was as follows. The urine sample $(100 \mathrm{ml}$.) was treated with $10 \mathrm{~N}-\mathrm{NaOH}(30 \mathrm{ml}$.$) , heated at$ $100^{\circ}$ for $1 \mathrm{hr}$., cooled, treated with $10 \mathrm{~N}-\mathrm{HCl}(33 \mathrm{ml}$.), steamdistilled into $4 \%(\mathrm{w} / \mathrm{v})$ salicylsulphonic acid $(10 \mathrm{ml}$.) until the distillate no longer reduced iodine, and the distillate titrated at $0^{\circ}$ with $1 \mathrm{mN}-\mathrm{KIO}_{3}$ in the presence of $1 \%(\mathrm{w} / \mathrm{v})$ sodium starch glycollate $(0.5 \mathrm{ml}$.) and $5 \%(\mathrm{w} / \mathrm{v}) \mathrm{KI}(5 \mathrm{ml}$.$) .$ A blank value obtained by similar treatment of normal urine (100 ml.) was subtracted. The approximate amount of $N$-acetyl-S-carbethoxycysteine $(A)$ was calculated from the relationship $A=5(B-0 \cdot 3 C)$, where $B$ was total $\mathrm{SH}$ (as determined by the iodometric titration) and $C$ was the total ethylmercapturic acid (as determined by the nitroprusside method), all three values $(A, B$ and $C$ ) being expressed as percentages of the total dose. When ethylmercapturic acid (2 mg.) and $N$-acetyl-S-carbethoxycysteine $(5 \mathrm{mg}$.) were added to normal rat urine $(100 \mathrm{ml}$.) and each component was determined by the methods described, the recovery values obtained were 95 and $84 \%$ respectively.

\section{RESULTS}

\section{Metabolism of urethane in the rat, rabbit and man}

The neutral fraction (Scheme 1) from the urine of 16 female rats which received five daily doses of $1 \mathrm{~g}$. of urethane $/ \mathrm{kg}$. (total dose, 16.6 g.), from the urine of two rabbits which received six daily doses of $1 \mathrm{~g}$. of urethane $/ \mathrm{kg}$. (total dose, $27 \cdot 5 \mathrm{~g}$.), and from the urine of two male patients who received two daily doses of $2 \mathrm{~g}$. of urethane (total dose, $8 \mathrm{~g}$.), showed the presence, by thin-layer chromatography in solvent systems $(c)$ and $(d)$, of urethane, $N$ hydroxyurethane and a mixture of $N$ - and $O$-acetyl$N$-hydroxyurethane. Two-dimensional thin-layer chromatography (first run in solvent $d$, followed by spraying with $2 \mathrm{~N}$-ammonia and running again in solvent $c$ after $1 \mathrm{hr}$.) showed that the spots corresponding to $N$ - and $O$-acetyl- $N$-hydroxyurethane gave $N$-hydroxyurethane. The acidic fraction (Scheme 1) contained ethylmercapturic acid and $N$-acetyl-S-carbethoxycysteine. The material obtained by elution of strips cut off the appropriate regions, after hydrolysis with $6 \mathrm{~N}$-hydrochloric acid at $100^{\circ}$ for $2 \mathrm{hr}$., showed the presence of compounds which were indistinguishable from $S$-ethylcysteine and $S$-carbethoxycysteine. No metabolite was detected in the methanol-ammonia fraction (Scheme 1) of the urine of the rat, rabbit and man. 
Glucuronide fraction (Scheme 1). This yielded a gum, which gave a naphtharesorcinol reaction, but attempts to fractionate or to prepare a crystalline tetra- $O$-acetyl methyl ester by the use of acetic anhydride and diazomethane were unsuccessful. Hydrolysis of the gum with bacterial $\beta$-glucuronidase at $\mathrm{pH} 5.5$ for $16 \mathrm{hr}$. at $37^{\circ}$, followed by ether extraction, yielded neither urethane nor $N$-hydroxyurethane. Samples $(200 \mathrm{ml}$.) of the aq. fraction 1 (Scheme 1) were freed from ether under reduced pressure, adjusted to $\mathrm{pH} \mathbf{5 . 5}$ with acetic acid, diluted with $0.2 \mathrm{M}$-acetate buffer (pH 5.5, $50 \mathrm{ml}$.) and incubated with ox-liver (Ketodase, $2 \mathrm{ml}$.) or bacterial $\beta$-glucuronidase $(0 \cdot 2 \mathrm{~g}$.), or with Takadiastase $(0.2 \mathrm{~g}$.) containing glucosaccharo-1 $\rightarrow$ 4lactone $\left(0.5 \mathrm{~g}\right.$.) at $37^{\circ}$ for $16 \mathrm{hr}$. The incubated mixtures were extracted with ether $(4 \times 50 \mathrm{ml}$.), the ether extracts dried (sodium sulphate), evaporated in vacuo and the urethane and $N$-hydroxyurethane contents of the residual gums quantitatively determined and compared with those of $200 \mathrm{ml}$. urine samples treated similarly, but containing no enzyme. No increase was observed. Glucuronides or ethereal sulphates of urethane or $N$-hydroxyurethane are probably not metabolites of urethane. Tsukamoto, Yoshimura \& Tatsumi (1963) were also unable to find urethane glucuronide in the urine of rabbits dosed with urethane.

Quantitative determination of urethane, N-hydroxyurethane, acetyl-N-hydroxyurethane, ethylmercapturic acid and $\mathrm{N}$-acetyl-S-carbethoxycysteine. $N$ Hydroxyurethane was determined as follows. The urine sample $\left(100 \mathrm{ml}\right.$.) was acidified at $0^{\circ}$ with acetic acid to $\mathrm{pH} 4 \cdot 0$, shaken with charcoal (1 g.), filtered, and the charcoal washed with water (10 ml.); the filtrate and washing were combined, neutralized with $\mathrm{N}$-sodium hydrogen carbonate, and evaporated at $40^{\circ}$ in vacuo; the residue was extracted with ethanol $(20 \mathrm{ml}$.), the ethanolic extract filtered, evaporated in vacuo, the residue dissolved in water $(8 \mathrm{ml}$.) and determinations were carried out as described in the Methods section. Acetyl-N. hydroxyurethane was similarly determined after treatment of urine samples $(100 \mathrm{ml}$.) with $4 \mathrm{~N}$ hydrochloric acid $\left(11 \mathrm{ml}\right.$.) for $16 \mathrm{hr}$. at $4^{\circ}$ and estimation of the $N$-hydroxyurethane content against a blank made up similarly from normal urine $(100 \mathrm{ml}$.) to which the determined amount of $N$-hydroxyurethane had been previously added. Further confirmation of the results were obtained by applying a measured volume of the ethanolic extract as streaks on thin-layer plates, developing the chromatograms in solvent $(c)$, eluting with ethanol the material scraped off the appropriate regions and estimating the hydroxyurethane and acetyl- $N$-hydroxyurethane content of the residues obtained after evaporation in vacuo of the eluates. Urethane, ethylmercapturic acid and $N$-acetyl-Scarbethoxycysteine were determined as described (above) on $100 \mathrm{ml}$. urine samples. The results obtained are given in Table 2.

\section{Metabolism of $\mathrm{N}$-hydroxyurethane in the rat and rabbit}

The neutral fraction (Scheme 1) from the urine of 20 female rats receiving seven daily doses $(0 \cdot 4 \mathrm{~g} . / \mathrm{kg}$.) of $N$-hydroxyurethane (total dose, $15 \mathrm{~g}$.), after concentration in vacuo, was applied as streaks on glass plates coated with silica gel of $0.50 \mathrm{~mm}$. thickness, developed in solvent (c), and the band corresponding to $N$-hydroxyurethane scraped off, eluted with ether, concentrated in vacuo, the residue rechromatographed in solvent $(d)$ and the elution process repeated. The ethereal eluate was dried (sodium sulphate), treated with phenyl isocyanate $\left(0.4 \mathrm{ml}\right.$.), evaporated in vacuo after $20 \mathrm{~min}$. at $22^{\circ}$, and the residual gum crystallized from benzenelight petroleum (b.p. 60-80 ) to yield phenylcarbamoyl- $N$-hydroxyurethane $(0 \cdot 365 \mathrm{~g}$.) as colourless plates; the m.p., mixed m.p. and infrared spectrum were identical with those of an authentic specimen. The fractions corresponding to $N$ - and

Table 2. Metabolites of urethane and N-hydroxyurethane in the urine of the rat, rabbit and man

Figures in parentheses are mean values.

\begin{tabular}{|c|c|c|c|c|c|}
\hline \multirow[b]{2}{*}{ Compound given } & \multirow[b]{2}{*}{ Species } & \multirow[b]{2}{*}{$\begin{array}{c}\text { Dose } \\
\text { (g. } / \mathrm{kg} . \text { ) }\end{array}$} & \multicolumn{3}{|c|}{ Metabolites* occurring in 24-hr. urine (\% of dose) } \\
\hline & & & $\begin{array}{c}\text { Acetyl- } N \text { - } \\
\text { hydroxyurethane }\end{array}$ & $\begin{array}{l}\text { Ethylmercapturic } \\
\text { acid }\end{array}$ & $\begin{array}{c}N \text {-Acetyl-S- } \\
\text { carbethoxycysteine }\end{array}$ \\
\hline Urethane & $\begin{array}{l}\text { Rat } \\
\text { Rabbit } \\
\text { Man }\end{array}$ & $\begin{array}{c}1 \cdot 0 \\
1 \cdot 0 \\
2 \mathrm{~g} \cdot / \text { adult } \\
\text { male }\end{array}$ & $\begin{array}{l}0 \cdot 1,0 \cdot 1,0 \cdot 2(0 \cdot 14) \\
0 \cdot 1,0 \cdot 2,0 \cdot 3(0 \cdot 2) \\
0 \cdot 5,0 \cdot 6(0 \cdot 6)\end{array}$ & $\begin{array}{l}0.09,0.1,0.2(0.13) \\
0.05,0.2,0.3(0.2) \\
0.06,0.2(0.13)\end{array}$ & $\begin{array}{l}1 \cdot 5,1 \cdot 8,2 \cdot 1(1 \cdot 8) \\
1 \cdot 8,2 \cdot 2,2 \cdot 2(2 \cdot 1) \\
0 \cdot 2,1 \cdot 5(0 \cdot 9)\end{array}$ \\
\hline$N$-Hydroxyurethane & $\begin{array}{l}\text { Rat } \\
\text { Rabbit }\end{array}$ & $\begin{array}{l}0.4 \\
0.4\end{array}$ & $\begin{array}{l}8 \cdot 5,9 \cdot 6,11 \cdot 0(9 \cdot 7) \\
9 \cdot 0,15,20(14 \cdot 7)\end{array}$ & $\begin{array}{l}0.4,0.7,0.7(0.6) \\
0.2,0.3,0.3(0.3)\end{array}$ & $\begin{array}{l}1 \cdot 7,2 \cdot 0,2 \cdot 0(1 \cdot 9) \\
1 \cdot 8,2 \cdot 2,2 \cdot 7(2 \cdot 2)\end{array}$ \\
\hline
\end{tabular}

* The amounts of urethane and $N$-hydroxyurethane excreted are given in Table 3 . 
$O$-acetyl- $N$-hydroxyurethane, obtained similarly, were hydrolysed with cold $\mathrm{N}$-hydrochloric acid and aq. $\mathrm{N}$-ammonia soln. to yield $N$-hydroxyurethane in varying amounts.

The fraction eluted off charcoal (Scheme 1), by chromatography in solvent systems $(a),(b)$ and $(e)$, contained a substance indistinguishable from $S$-ethylcysteine.

The gum obtained after evaporation in vacuo of the chloroform from the acidic fraction (Scheme 1) was applied as streaks on sheets of $3 \mathrm{MM}$ chromatography paper. Strips corresponding to the $R_{F}$ region of $S$-ethylmercapturic acid were cut off the chromatograms after development in solvent $(b)$, eluted with chloroform, the chloroform extract was dried (sodium sulphate), concentrated in vacuo to about $10 \mathrm{ml}$., extracted with $5 \%(\mathrm{w} / \mathrm{v})$ sodium carbonate $(3 \times 15 \mathrm{ml}$.), the aqueous extract acidified to $\mathrm{pH} 2$ with hydrochloric acid and extracted with chloroform $(4 \times 20 \mathrm{ml}$.); the chloroform extracts were dried (sodium sulphate), evaporated to dryness in vacuo, the residual gum was dissolved in methanol (2 ml.), applied as streaks on glass plates coated with silica gel of $0.5 \mathrm{~mm}$. thickness, the chromatograms were developed in solvent system (e), and the band corresponding to the $R_{F}$ region of ethylmercapturic acid $\left(R_{F}, 0.65-0.70\right)$ was scraped off and eluted with chloroform (15 ml.). The gum obtained after drying (sodium sulphate) and evaporating the chloroform extract was dissolved in acetone $(5 \mathrm{ml}$.), neutralized with dicyclohexylamine, evaporated in vacuo, the residue washed with cold acetone $(5 \mathrm{ml}$.$) , dissolved$ in the minimum volume of warm ethanol and diluted with warm acetone until the solution became cloudy. On cooling, the solution deposited a solid (5 mg.), which did not melt below $300^{\circ}$ and was discarded. Similar treatment of the filtrate with acetone yielded a second crop (15 mg.), m.p. $206^{\circ}$, which was not identified, and a third crop ( $2 \mathrm{mg}$.) of dicyclohexylammonium $S$-ethylmercapturate, identical in its m.p., mixed m.p. and chromatographic behaviour with an authentic specimen.

A sample of the gum obtained after evaporation in vacuo of the acidic fraction (Scheme 1) was applied as streaks on $3 \mathrm{MM}$ chromatography paper, strips were cut off $\left(R_{F}, 0.75-0.83\right)$ the chromatograms developed in solvent $(b)$ and eluted with chloroform. Similar hydrolytic and chromatographic experiments to those described for the corresponding fraction of urine from rats and rabbits dosed with urethane indicated the presence of ethylmercapturic acid, ethylmercapturic acid sulphoxide and $N$-acetyl-S-carbethoxycysteine as metabolites of $N$-hydroxyurethane.

Glucuronide fraction (Scheme 1). Similar results were obtained to those described for urines from animals dosed with urethane.

Quantitative determination of urethane, N-hydroxy- urethane, acetyl-N-hydroxyurethane, ethyl mercapturic acid and $N$-acetyl-S-carbethoxycysteine. $N$ Hydroxyurethane was determined directly on filtrates $(3.5 \mathrm{ml}$.) of urine samples $(10 \mathrm{ml}$.) which had been decolorized with charcoal (see the Methods section). The other metabolites were determined as is described for urethane metabolites. The results obtained are given in Table 2.

\section{Bile of the rat after dosing with urethane or $\mathrm{N}$-hydroxyurethane}

Urethane. Two male rats (approx. body wt. 250 g.) with bile fistulae (Boyland, Ramsay \& Sims, 1961) were given four daily intraperitoneal injections of $0.1 \mathrm{~g}$. of urethane dissolved in $1 \mathrm{ml}$. of water, and the bile was collected twice daily and stored under toluene at $-5^{\circ}$. The bile was freed from toluene by aspiration at the water pump, acidified with acetic acid to $\mathrm{pH} 4 \cdot 0$, centrifuged, the supernatant stirred with charcoal (5 g.), the charcoal filtered off, washed with water $(500 \mathrm{ml}$.), eluted with methanol (100 ml.) containing aq. ammonia soln. (sp.gr. 0.88, $5 \mathrm{ml}$.), the eluate concentrated in vacuo and the residual gum examined by paper chromatography in butan-1-ol-acetic acid-water (2:1:1, by vol.) and also in solvents $(a)$ and $(b)$. A substance indistinguishable from $S$-ethylglutathione (Roberts \& Warwick, 1958), which gave $S$-ethylcysteine, glutamic acid and glycine on hydrolysis with hydrogen bromide (sp.gr. 1.7) at $100^{\circ}$ for $2 \mathrm{hr}$., was obtained.

N-Hydroxyurethane. Examination of the bile of rats dosed with $N$-hydroxyurethane revealed the presence of a glutathione derivative which, after hydrolysis with hydrogen bromide (sp.gr. 1.7) at $100^{\circ}$ for $2.5 \mathrm{hr}$., yielded $S$-ethylcysteine sulphoxide, $S$-ethylcysteine, glutamic acid and glycine. It was probably $S$-ethylglutathione sulphoxide since it was also detectable with reagents (iii), (v) and (vi), but not with reagent (ii).

\section{Interconversion of carbamates and \\ $\mathrm{N}$-hydroxycarbamates as a general phenomenon in the rat, rabbit and man}

Adult female rats (approx. body wt. 200 g.) were given single doses of $0 \cdot 3-1 \cdot 0 \mathrm{~g}$. of carbamate $/ \mathrm{kg}$. or $0.02-0.4 \mathrm{~g}$. of $N$-hydroxycarbamate $/ \mathrm{kg}$., intraperitoneally; rabbits (approx. body wt. 2 kg.) were given $1 \mathrm{~g}$. of urethane $/ \mathrm{kg}$. or $0.2 \mathrm{~g}$. of $N$-hydroxyurethane $/ \mathrm{kg}$. by intraperitoneal injection; four adult male patients were given $2 \mathrm{~g}$. of urethane each by mouth. The urine was collected during the first and second $24 \mathrm{hr}$. periods separately, except for patients, whose urines were collected for the first $24 \mathrm{hr}$. period only. Each urine sample was decolorized with charcoal. For carbamate urines, one-half was 
Table 3. Interconversion of carbamates and $\mathrm{N}$-hydroxycarbamates in the animal body

Figures in parentheses are mean values.

\begin{tabular}{|c|c|c|c|c|c|c|}
\hline \multirow[b]{3}{*}{ Compound given } & \multirow[b]{3}{*}{ Species } & \multirow{3}{*}{$\begin{array}{c}\text { Dose } \\
\text { (g./kg.) }\end{array}$} & \multicolumn{4}{|c|}{ Metabolites in urine ( $\%$ of dose) } \\
\hline & & & \multicolumn{2}{|c|}{$\mathrm{R} \cdot \mathrm{O} \cdot \mathrm{CO} \cdot \mathrm{NH}_{2}$} & \multicolumn{2}{|c|}{$\mathrm{R} \cdot \mathrm{O} \cdot \mathrm{CO} \cdot \mathrm{NH} \cdot \mathrm{OH}$} \\
\hline & & & First day & Second day & First day & Second day \\
\hline bamates & & & & & & \\
\hline$=$ Methyl & Rat & $1 \cdot 0$ & $\begin{array}{c}1 \cdot 5,1 \cdot 5,1 \cdot 8,4 \cdot 6 \\
4 \cdot 6,5 \cdot 8(3 \cdot 3)\end{array}$ & $\begin{array}{c}-,-, 4 \cdot 4,4 \cdot 6, \\
5 \cdot 3,5 \cdot 4(4 \cdot 9)\end{array}$ & $\begin{array}{l}0.004,0.008 \\
0.008,0.01, \\
0.01,0.01(0.008)\end{array}$ & $\begin{array}{l}-,-, 0.002, \\
0.01,0.20(0.06)\end{array}$ \\
\hline Ethyl & Rat & $1 \cdot 0$ & $\begin{array}{l}0 \cdot 8,0 \cdot 9,1 \cdot 0,1 \cdot 8 \\
1 \cdot 9,2 \cdot 2,2 \cdot 2, \\
2 \cdot 8(1 \cdot 7)\end{array}$ & $\begin{array}{l}-,-,-, 0.2, \\
0.2,0.2,0.9 \\
0.9(0.5)\end{array}$ & $\begin{array}{c}0.06,0.06,0.07 \\
0.08,0.08,0.08 \\
0.1,0 \cdot 1(0.08)\end{array}$ & $\begin{array}{l}-,-,-, 0.01, \\
0.01,0.03,0.03, \\
0.02(0.02)\end{array}$ \\
\hline Ethyl & Rabbit & $1 \cdot 0$ & $0 \cdot 4,1 \cdot 2,1 \cdot 6(1 \cdot 1)$ & $0.5,0 \cdot 6,0 \cdot 7(0.6)$ & $\begin{array}{l}0.08,0 \cdot 08,0 \cdot 2 \\
(0 \cdot 12)\end{array}$ & $\begin{array}{l}0.01,0.02,0.02 \\
(0.02)\end{array}$ \\
\hline Ethyl & Man & $\begin{array}{l}2 \mathrm{~g} . / \text { adult } \\
\text { male/day }\end{array}$ & $\begin{array}{c}0.04,0.04,0.8 \\
1.0(0.5)\end{array}$ & - & $\begin{array}{c}0.09,0 \cdot 1,0 \cdot 2, \\
0.2(0 \cdot 15)\end{array}$ & - \\
\hline n-Propyl & Rat & $1 \cdot 0$ & $1 \cdot 9,2 \cdot 6,2 \cdot 6(2 \cdot 4)$ & $1 \cdot 6,1 \cdot 9,2 \cdot 4(2 \cdot 0)$ & $\begin{array}{r}0.001,0.005 \\
0.01(0.005)\end{array}$ & $\begin{array}{l}0,0.002,0.002 \\
(0.001)\end{array}$ \\
\hline$n$-Butyl & Rat & 0.3 & 0.8 & 0.8 & 0.09 & 0.06 \\
\hline$n$-Butyl & Rat & $0 \cdot 4$ & $1 \cdot 0$ & $1 \cdot 1$ & 0.08 & 0.08 \\
\hline
\end{tabular}

(B) N-Hydroxycarbamates

$(\mathrm{R} \cdot \mathrm{O} \cdot \mathrm{CO} \cdot \mathrm{NH} \cdot \mathrm{OH})$

$\begin{aligned} \mathbf{R}= & \text { Methyl } \\ & \text { Ethyl } \\ & \text { Ethyl } \\ & \text { Ethyl } \\ & \text { Ethyl } \\ & \text { Ethyl } \\ & \text { Ethyl }\end{aligned}$

\begin{tabular}{|c|c|c|c|c|c|}
\hline at & 0.4 & $2 \cdot 5,2 \cdot 9,6 \cdot 8(4 \cdot 1)$ & $4 \cdot 8,5$ & $27,30,3$ & $1 \cdot 5,5$ \\
\hline Rat & 0.02 & $3,0.5,0.8(0.5)$ & - & $0.2,0.5,0.5(0.4)$ & \\
\hline Rat & 0.05 & $(0.9)$ & $0.1,0.2,0.4(0.2)$ & & 0 . \\
\hline & & & 0.2 & & \\
\hline$R g$ & & & 0.2 , & & 0.9 \\
\hline$R \varepsilon$ & 0.4 & & $0 \cdot 4$, & & \\
\hline & 0.20 & & $\begin{array}{r}0,0.0 \\
\quad(0.0\end{array}$ & 15 , & 2 . \\
\hline $\mathbf{a} \mathbf{a}$ & 0.2 & & 1.9 & & \\
\hline & 0.2 & $0.3,0.6,0.6(0.5)$ & $0.5,0.6,0.6(0.6)$ & $6 \cdot 1,8 \cdot 8,9 \cdot 1(8 \cdot 0)$ & \\
\hline
\end{tabular}

neutralized with $\mathrm{N}$-sodium hydroxide, evaporated in vacuo at $40^{\circ}$, the residue shaken with ethanol $(20 \mathrm{ml}$.), the mixture filtered and the residue washed with ethanol $(10 \mathrm{ml}$.); the combined filtrate and washings were evaporated in vacuo, the residue was dissolved in water $(8 \mathrm{ml}$.) and the $N$-hydroxycarbamate content determined as previously described. For $N$-hydroxycarbamate urines, portions $(3.5 \mathrm{ml}$.) of the decolorized samples were treated with $8 \%(\mathrm{w} / \mathrm{v})$ sodium amminoprusside and the $N$ hydroxycarbamate content was determined as previously described. Carbamates were determined on the remainder of the urine samples, as previously described. The results obtained are given in Table 3.

Gastric juice of the rat and hamster after dosing with urethane or $\mathrm{N}$-hydroxyurethane

Adult female rats (approx. body wt. 250 g.) and male hamsters (approx. body wt. 85 g.) established with gastric fistulae were given intraperitoneal doses of urethane $(0.8 \mathrm{~g} . / \mathrm{kg}$. $)$ or $N$-hydroxyurethane
$(0.32 \mathrm{~g} . / \mathrm{kg}$.$) . The gastric juice was withdrawn after$ varying time-intervals, neutralized with aq. $5 \%$ (w/v) sodium carbonate, evaporated in vacuo, the residue shaken with chloroform $(10 \mathrm{ml}$.$) , filtered$ and washed with chloroform $(10 \mathrm{ml}$.); the combined chloroform solutions were dried (sodium sulphate), evaporated in vacuo, the residue was dissolved in water $(3.5 \mathrm{ml}$.) and the $N$-hydroxyurethane content determined with the $0.8 \%(w / v)$ sodium amminoprusside reagent. The results obtained are shown in Table 4.

\section{DISCUSSION}

The process of $N$-hydroxylation appears to be an essential step in carcinogenesis by some aromatic amino and acetamido derivatives (Cramer, Miller \& Miller, 1960; Nelson \& Troll, 1961; Uehleke, 1963; Boyland, Manson \& Nery, 1963). Acyl derivatives of $N$-hydroxyamino acids have also been isolated from microbial fermentations. These include $N$-formyl- $N$-hydroxyglycine (hadacidin; Kaczka, 
Table 4. Secretion of N-hydroxyurethane in the stomachs of rats and hamsters

\begin{tabular}{|c|c|c|c|c|c|c|}
\hline Compound given & Species & $\begin{array}{l}\text { No. of } \\
\text { animals }\end{array}$ & $\begin{array}{c}\text { Dose } \\
\text { (g./kg.) }\end{array}$ & $\begin{array}{l}\text { Time after } \\
\text { dosing } \\
\text { (hr.) }\end{array}$ & $\begin{array}{l}\text { Vol. of } \\
\text { gastric juice } \\
\text { collected } \\
\text { (ml.) }\end{array}$ & $\begin{array}{c}\text { Concn. of } \\
N \text {-hydroxy- } \\
\text { urethane } \\
(\mu \mathrm{g} . / \mathrm{ml} .)\end{array}$ \\
\hline Urethane & Rat & 4 & $0 \cdot 8$ & $\begin{array}{r}4 \\
20 \\
28\end{array}$ & $\begin{array}{l}20 \\
20 \\
18\end{array}$ & $\begin{array}{l}4 \cdot 8 \\
1 \cdot 1 \\
0\end{array}$ \\
\hline Urethane & Hamster & 3 & 0.8 & $\begin{array}{r}4 \\
20 \\
28 \\
44\end{array}$ & $\begin{array}{l}7 \cdot 5 \\
7 \cdot 0 \\
7 \cdot 0 \\
6 \cdot 2\end{array}$ & $\begin{array}{c}18 \\
6 \cdot 3 \\
3 \cdot 0 \\
0\end{array}$ \\
\hline$N$-Hydroxyurethane & Rat & 2 & 0.32 & $\begin{array}{r}4 \\
20\end{array}$ & $\begin{array}{l}4 \cdot 2 \\
4 \cdot 2\end{array}$ & $\begin{array}{r}68 \\
6\end{array}$ \\
\hline
\end{tabular}

Gitterman, Dulaney \& Folkers, 1962), $N$-hydroxyisoleucine, which occurs in aspergillic acid (Dutcher, 1958), $N$-hydroxylysine in mycobactin (Snow, 1954) and $N$-hydroxytyrosine in mycelianamide (Birch, 1957). Hydroxamic acids are produced by the chemical oxidation of amides, aldehyde-ammonias and primary amines by hydrogen peroxide or persulphuric acid (Bamberger, 1900, 1902); the addition of hydroxylamine to fumaric acid to yield $N$-hydroxyaspartic acid is catalysed by aspartase (Emery, 1963). $N$-Formyl- $N$-hydroxyglycine (hadacidin), $N$-hydroxyurea (Stearns, Losee \& Bernstein, 1963) and hydroxylamine (Cudkowicz, 1955) have anti-tumour properties. Hydroxyurethane is carcinogenic (Berenblum et al. 1959) and causes chromosome breaks in the root tips of Vicia faba (Boyland, Nery, Peggie \& Williams, 1963).

When urethane is administered to the rat, rabbit and man, it is oxidized by a process of $N$-hydroxylation to yield $N$-hydroxyurethane and its $N$ - and $O$-acetyl derivatives (see Table 2). The latter compound is probably formed from the chemical rearrangement of the $N$-isomer. The fact that only small amounts of these metabolites are excreted in the urine may not be indicative of the extent to which $N$-hydroxylation actually occurs in the animal since, in the rat, small doses of administered $N$-hydroxyurethane are metabolized (see Table 3). Thus, of a dose of $20 \mathrm{mg} . / \mathrm{kg}$., less than $0.5 \%$ is excreted in the urine in $24 \mathrm{hr}$., whereas over $30 \%$ of a dose of $400 \mathrm{mg} . / \mathrm{kg}$. is excreted unchanged during the same period.

The presence of $S$-ethyl derivatives of cysteine in the urines of animals dosed with urethane and $N$-hydroxyurethane indicates that, like many other classes of radiomimetic carcinogens, these substances are biological alkylating agents and, as such, their carcinogenic effects may be partly explained. However, this process apparently occurs only to a minor extent since $S$-ethylcysteine derivatives are excreted in small amounts only. A process which appears to occur to a larger extent is that of $S$ - carbethoxylation; but whether $N$-acetyl-S-carbethoxycysteine is in itself a carcinogen is not known. N-Hydroxyurethane, but not urethane, reacts in vitro with cysteine and $N$-acetylcysteine in aqueous sodium hydrogen carbonate solutions to yield small amounts of the $S$-ethyl and $S$-carbethoxy derivatives. A solution of $N$-acetyl-S-carbethoxycysteine in $2 \mathrm{~N}$-sodium hydroxide at $23^{\circ}$ slowly yields $S$-ethylcysteine, a reaction analogous to that described by Otto \& Rossing (1886) for the alkaline degradation of the $S$-ethyl and $S$-phenyl esters of ethyl thiocarbonate, i.e.

$$
\mathrm{Et} \cdot \mathrm{O} \cdot \mathrm{CO} \cdot \mathrm{S} \cdot \mathrm{R} \stackrel{\mathrm{OH}^{-}}{\longrightarrow} \mathrm{Et} \cdot \mathrm{S} \cdot \mathrm{R}+\mathrm{CO}_{2}
$$

where $\mathrm{R}$ is ethyl, phenyl or $N$-acetylcysteinyl. Thus at least two metabolites of urethane, i.e. $N$-hydroxyurethane and $N$-acetyl-S-carbethoxycysteine, may produce $S$-ethylcysteinyl derivatives in vivo. However, Berenblum et al. (1959) have shown that the $N$-carbethoxy derivatives of several amino acids are not lung carcinogens and do not have an initiating action on skin carcinogenesis, but diethyl carbonate is an initiator of skin carcinogenesis.

In view of these findings it is probable that $N$-hydroxyurethane plays an important role in urethane carcinogenesis, but the mechanism of its action is still obscure. In addition to its alkylating and carbethoxylating properties, $N$-hydroxyurethane may give rise to hydroxylamine, nitroxyl or hyponitrous acid. In this connexion, reference may be made to the fact that the ability, in descending order of reactivity, of carbamates, $N$-hydroxyurea and urea to give cyanate in alkaline media is related to the relative stabilities of the alkoxy, hydroxyamido and amido anions $\left(\mathrm{A}^{-}\right)$produced in the reaction:

$$
\begin{aligned}
\mathrm{H}_{2} \mathrm{~N}-\mathrm{CO}-\mathrm{A} & \stackrel{\mathrm{OH}^{-}}{\longrightarrow} \mathrm{HN}=\mathrm{CO} \cong \mathrm{A} \\
\longrightarrow & \mathrm{HNCO}+\mathrm{A}^{-}
\end{aligned}
$$


$N$-Hydroxycarbamates do not give this reaction but may produce hydroxyamido anions via the $\mathrm{S}_{\mathrm{N}} 2$-type transition state (II):

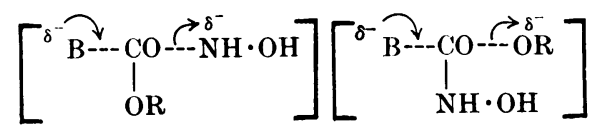

(II)

This occurs when $\mathrm{B}$ is $\mathrm{RS}^{-}$(e.g. cysteinyl), $\mathrm{HO}^{-}$or $E^{-} 0^{-}$, yielding an $S$-carbethoxy thiol ester, an alkyl hydrogen carbonate and a dialkyl carbonate respectively and, probably, hydroxylamine. Similarly when $\mathrm{B}$ is $\mathrm{HO}^{-}, N$ - and $O$-alkyl- $N$-hydroxyurethanes yield the corresponding $N$ - and $O$. alkylhydroxylamines (Nicolaus, Pagani \& Testa, 1962). When $B$ is ammonia, the products are $N$-hydroxyurea and an alcohol, probably formed via transition state (III) (E. Boyland \& R. Nery, unpublished work). A similar reaction occurs between urethane and hydroxylamine in alkaline media, the products being $N$-hydroxyurea and ethanol (Deghenghi, 1960). Acid hydrolysis of hydroxamic acids or their $N$ - and $O$-alkyl derivatives also yields hydroxylamine or the corresponding alkylhydroxylamines (Yale, 1943).

Administration of $\mathrm{N}$-hydroxyurea to human subjects gives rise to hydroxylamine, which specifically cleaves thiol esters (e.g. acetyl-coenzyme A) and acyl phosphates, thereby producing acetohydroxamic acid (Fishbein \& Carbone, 1963). Hydroxylamine is readily oxidized to nitroxyl (NOH), which rapidly dimerizes to hyponitrous acid (Thorne \& Roberts, 1948), or it may disproportionate via the nitroxyl radical, again to form hyponitrous acid (Nast \& Foppl, 1950). The latter reaction is also given by organic $N$-substituted hydroxylamines (Sidgwick, 1945). Nitroxyl, which is also an intermediate during photosynthesis of nitrogenous compounds in plants (Baly, Heilbron \& Hudson, 1922), may react with aldehydes to give hydroxamic acids. Such reactions between aldehydes and nitroxyl or compounds capable of yielding nitroxyl, e.g. Piloty's acid, are known (Angeli, 1897, 1908). Bendich, Borenfreund, Korngold, Krim \& Balis (1963) have shown that hydroxylamine, hyponitrous acid, $N$-hydroxyurea and $N$-hydroxyurethane are capable of producing similar mainchain cleavages in human leucocyte DNA in addition to breakage and rearrangement of metaphase chromosomes in Chinese hamster cells. Hydroxylamine fragments mammalian and bacteriophage DNA (Bendich, Borenfreund, Korngold \& Krim, 1963), is a mutagen (Freese, Bautz \& Freese, 1961) and is an inhibitor of catalase (Boyland \& Gallico, 1952).

These results indicate that urethane may exert its carcinogenic effects after conversion into $N$-hydroxyurethane by one or more of the following processes: (1) biological alkylation, (2) biological carbethoxylation, probably an intermediate process leading to (1), and (3) reaction of hydroxylamine, nitroxyl or hyponitrous acid.

The enhanced carcinogenicity of urethane, as compared with the other analogues (e.g. methyl, $n$-propyl and $n$-butyl carbamates) may be due to the following: (1) urethane is $N$-hydroxylated apparently to a greater extent in the animal body; (2) urethane is metabolized more rapidly, thus presenting a higher concentration of carcinogen to the tissues during a shorter time; (3) the apparent specificity of the ethyl group, since variation of this in the carbamate (or, possibly, $N$-hydroxycarbamate) series results in less activity. Urethane and $N$-hydroxyurethane have the same activity in inducing cancer and in inhibiting the growth of the Walker carcinoma in rats.

If $N$-hydroxylation is the critical process in carcinogenesis, or chemotherapy by urethane, it is difficult to understand why the $N$-hydroxy analogue should not be more potent; this may be due to the fact that, above a certain critical concentration, $N$-hydroxyurethane is rapidly excreted unchanged in the urine to a large extent (see Table 3). Since the carbamates and their $N$-hydroxy analogues are interconvertible in the animal body, it is possible that a certain optimum carbamate: $N$-hydroxycarbamate concentration ratio is necessary for maximum carcinogenic activity. If the production of hydroxylamine, nitroxyl and hyponitrous acid in vivo is critical, then variation of the alkyl group in the $N$-hydroxycarbamate series may not produce significant differences in activity.

Urethane and $N$-hydroxyurethane both produce chromosome damage in the tissues of rats (P. C. Koller, personal communication). $N$-Hydroxyurethane is an essential and active metabolite in the biological action of urethane, as is indicated by the production of chromosome damage in root tips of Vicia faba by $N$-hydroxyurethane, whereas urethane is inactive in this system. Rat tissues can convert urethane into the active $N$-hydroxy derivative but it is probable that the plant tissues are unable to carry out this biochemical conversion. $\mathrm{N}$-Hydroxyurethane and urethane are similar in action to hydroxyurea, in which case the alkylating and carbethoxylating functions of $N$-hydroxyurethane are probably less important than the hydroxylamine residue of the molecule.

We thank Mr G. S. Ramsay for the preparation of bileand gastric-fistulated rats and hamsters, Mr Errol Gomès for technical assistance, and Dr G. Boxer of Merck, Sharp and Dohme and Professor L. Young for gifts of $N$-hydroxyurea and ethylmercapturic acid respectively. This investigation has been supported by grants to the Chester Beatty Research 
Institute (Institute of Cancer Research: Royal Cancer Hospital) from the Medical Research Council and the British Empire Cancer Campaign for Research, and by the Public Health Service Research Grant no. CA-03188-08 from the National Cancer Institute, U.S. Public Health Service.

\section{REFERENCES}

Angeli, A. (1897). Gazz. chim. ital. 27, 357.

Angeli, A. (1908). Samml. chem. Vortr. 13, 1.

Baly, E. C. C., Heilbron, I. M. \& Hudson, D. P. (1922). J. chem. Soc. 121, 1078.

Bamberger, E. (1900). Ber. dtsch. chem. Ges. 33, 1781.

Bamberger, E. (1902). Ber. dtsch. chem. Ges. 35, 4293.

Beikert, A. (1951). Z. ges. exp. Med.117, 10.

Bendich, A., Borenfreund, E., Korngold, G. C. \& Krim, M. (1963). Fed. Proc. 22, 582.

Bendich, A., Borenfreund, E., Korngold, G. C., Krim, M. \& Balis, M. E. (1963). Proc. Symp. Nucleic Acids and their Role in Biology, Inst. Lombardo di Sci. Lettere, Milan, (in the Press).

Berenblum, I., Ben-Ishai, D., Haran-Ghera, N., Lapidot, A., Simon, E. \& Trainin, N. (1959). Biochem. Pharmacol. $2,169$.

Berenblum, I. \& Trainin, N. (1960). Science, 132, 40.

Berenblum, I. \& Trainin, N. (1961). Science, 134, 2045.

Birch, A. J. (1957). Proc. chem. Soc., Lond., p. 233.

Boyland, E. \& Gallico, E. (1952). Brit. J. Cancer, 6, 160.

Boyland, E. \& Koller, P. C. (1954). Brit. J. Cancer, 8, 677.

Boyland, E., Manson, D. \& Nery, R. (1963). Biochem. J. 86, 263.

Boyland, E. \& Nery, R. (1964a). Analyst, 89, 95.

Boyland, E. \& Nery, R. (1964b). Analyst, 89, 502.

Boyland, E., Nery, R., Peggie, K. S. \& Williams, K. (1963). Biochem. J. 89, 113 P.

Boyland, E., Ramsay, G. S. \& Sims, P. (1961). Biochem. J. $78,376$.

Boyland, E. \& Rhoden, E. (1949). Biochem. J. 44, 528.

Cramer, J. W., Miller, J. A. \& Miller, E. C. (1960). J. biol. Chem. 235, 885.

Cudkowicz, G. (1955). Tumori, 41, 181.

Deghenghi, R. (1960). Org. Synth. 40, 60.

Devaux, G., Mesnard, P. \& Cren, J. (1963). Prod. pharm. 18, 221.

Doell, R. G. \& Carnes, W. H. (1962). Nature, Lond. 194, 588.

Dutcher, J. D. (1958). J. biol. Chem. 232, 785.

Emery, T. F. (1963). Biochemistry, 2, 1041.

Fiore-Donati, L., Chieco-Bianchi, L., de Benedictis, G. \& Maiorano, G. (1961). Nature, Lond., 190, 278.

Fishbein, W. N. \& Carbone, P. P. (1963). Science, 142, 1069.

Freese, E., Bautz, E. \& Freese, E. B. (1961). Proc. nat. Acad. Sci., Wash., 47, 845.

Garcia, H. (1963). Biologica, 34, 11.

Haddow, A. \& Sexton, W. A. (1946). Nature, Lond., 157, 500.

Harley-Mason, J. \& Archer, A. A. P. G. (1958). Biochem.J. $69,60 \mathrm{P}$.
Kaczka, E. A., Gitterman, C. O., Dulaney, E. L. \& Folkers, K. (1962). Biochemistry, 1, 340.

Kawamoto, S., Ida, N., Kirschbaum, A. \& Taylor, H. G. (1958). Cancer Res. 18, 725.

Kawamoto, S., Kirschbaum, A., Ibanez, M. L., Trentin, J. J. \& Taylor, H. G. (1961). Cancer Res. 21, 73.

Knight, R. H. \& Young, L. (1958). Biochem. J. 70, 111.

Law, L. W. \& Precerutti, A. (1963). Nature, Lond., 200, 693.

Loge, J. P. \& Rundles, R. W. (1951). Blood, 4, 201.

Maw, G. A. (1956). Biochem. J. 63, 116.

Nast, R. \& Foppl, I. (1950). Z. anorg. Chem. 263, 310.

Nelson, N. \& Troll, W. (1961). Fed. Proc. 20, 41.

Nettleship, A. \& Henshaw, P. S. (1943). J. nat. Inst. Cancer, 4, 309.

Nicolaus, B. J. R., Pagani, G. \& Testa, E. (1962). Helv. chim. acta, 47, 1381.

Otto, R.\& Rossing, A. (1886). Ber.dtsch.chem.Ges.19, 1227.

Paterson, E., ApThomas, I., Haddow, A. \& Watkinson, J. M. (1946). Lancet, i, 677.

Pirie, N. W. \& Hele, T. S. (1933). Biochem. J. 27, 1116.

Roberts, J. J. \& Warwick, G. P. (1958). Biochem. Pharmacol. 1, 60.

Salaman, M. H. \& Roe, F. J. C. (1953). Brit. J. Cancer, 7, 472.

Schoental, R. \& Rive, D. J. (1963). Biochem. J. 87, 22 P.

Shubik, P., Della Porta, G., Pietra, G., Tomatis, L., Rappaport, H., Saffiotti, U. \& Tóth, B. (1961). In Henry Ford Hosp. Symp.; Biological Interactions in Normal and Neoplastic growth, pp. 285-297. Ed. by Brennan, M. J. \& Simpson, W. L. London: J. and A. Churchill.

Sidgwick, N. V. (1945). The Organic Chemistry of Nitrogen, p. 613. Oxford: Oxford University Press.

Skipper, H. E., Bryan, C. E., White, C. \& Hutchison, O. S. (1948). J. biol. Chem. 173, 371.

Smith, J. N. \& Williams, R. T. (1949). Biochem. J. 44, 242.

Snow, G. A. (1954). J. chem. Soc. p. 2588.

Stearns, B., Losee, K. A. \& Bernstein, J. (1963). J. med. Chem. 6, 201.

Tannenbaum, A. (1961). Acta Un. int. Cancr. 17, 72.

Tannenbaum, A., Vesselinovitch, S. D., Maltoni, C. \& Stryzak-Mitchell, D. (1962). Cancer Res. 22, 1362.

Thompson, A. E. R., Barnsley, E. A. \& Young, L. (1963a). Biochem. J. 86, 145.

Thompson, A. E. R. \& Young, L. (1960). Biochem. J. 76, $62 \mathrm{P}$.

Thompson, J. F., Arnold, W. N. \& Morris, C. J. (1963b). Nature, Lond., 197, 380.

Thorne, P. C. L. \& Roberts, E. R. (1948). Inorganic Chemistry, p. 71. London: Gurney and Jackson.

Toennies, G. \& Kolb, J. J. (1951). Analyt. Chem. 23, 823.

Toth, B., Della Porta, G. \& Shubik, P. (1961). Brit. J. Cancer, 15, 322.

Tsukamoto, H., Yoshimura, H. \& Tatsumi, K. (1963). Chem. Pharm. Bull. 11, 1134.

Uehleke, H. (1963). Biochem. Pharmacol. 12, 219.

Yale, H. L. (1943). Chem. Rev. 33, 209. 